\title{
Illegal Uses of the Russian Maternity Capital
}

\author{
S. RUSSKIKH*
}

\begin{abstract}
*Svetlana Russkikh - PhD Student in Sociology, University of Paris Descartes; The Institute for Demographic Studies (INED). Address: 12 l’Ecole de Médecine St., Paris, 75006, France. E-mail: svetlana.russkikh@gmail.com

Citation: Russkykh S. (2018) Illegal Uses of the Russian Maternity Capital. Mir Rossii, vol. 27, no 3, pp. 180-197. DOI: 10.17323/1811-038X-2018-27-3-180-197
\end{abstract}

This paper deals with the contemporary Russian pro-natalist policy, focusing on the social benefit program "Maternity Capital". The main goal of this program is to increase the fertility rate, especially the birth of a second child. I analyze the legal and illegal uses of this program. First, I identify how recipient families intend to improve their living standards with the Maternity Capital. To this end, three types of legal uses are introduced: the acquisition of a first home, the expansion of the living space and the funding of a building project. Secondly, I show that these uses sometimes conflict with administrative, economic and personal constraints. In order to overcome these difficulties, some families chose to use the Maternity Capital in an illegal way. Thirdly, I argue that these illegal uses belong to three categories: fraudulent use, diverted use and subverted use. My claim is that: 1) Maternity Capital has some limits in its practical application; and 2) families illegally use the Maternity Capital in order to circumvent practical difficulties, but not the intent of the program.

Key words: Maternity Capital, fraud, illegal caching, Family policy, Pro-natalist policy, Russia

\section{Introduction}

Since the dissolution of the Soviet Union in 1991, Russia has been facing a demographic crisis defined by the absence of population renewal [Vishnevsky 2009, p. 5]. The fertility rate dropped to 1.2 children per woman in 1999-2000, when the mortality rate strongly 
increased (life expectancy went from 63 years in 1990 to 58 years in 1996). This crisis has triggered a significant diminution of the Russian population which has not been compensated for by immigration. Between 1991 and 2010, 5 million people were lost [Rosstat 2016]. Russia is considered the only developed country with such a demographic decline [Radvanyi, Laruelle, Pawlotsky 2016, p. 40].

In 2007, the President, Vladimir Putin, defined this demographic situation as "a threat to the whole nation"1. In the course of that year, the federal government introduced an ambitious pro-natalist policy [Rivkin-Fish 2010; Chernova 2011; Chernova 2012; Pecherskaya 2012]. Even though the Russian State Statistical Service showed a slightly increasing birth rate since 2012, the newly established policy is a controversial topic among Russian and international demographers [Avdeeva 2011; Frejka, Zakharov 2012; Zakharov 2008; Arkhangelskij 2014; Slonimczyk, Yurko 2014].

In the frame of the pro-natalist policy, a new social benefit program called "Maternity Capital" (Russian: Materinskij Kapital) was developed ${ }^{2}$. This is a one-time monetary payment ( $2007-250,000$ rubles [3,600 euros]; $2015-453,026$ rubles [7,000 euros]) to families with at least two children, after the birth of the youngest child. The remittance of this sum is handled by the Pension Fund (Russian: Pensionnyj Fond).

The Pension Fund allows the money to be used only for: 1) the purchase of a dwelling, 2) the education of the children, 3) the pension of the mother, or 4) payment for services assisting the social adaptation and integration of children with disabilities (this use was introduced in 2016). A large majority of recipients (more than 90\%) chose the purchase of a dwelling (Report of the Pension Fund 2016).

In this paper, I specifically focus on the illegal uses of the Maternity Capital. Temkina et al. [2016, p. 112] show that some recipients consider circumventing the rules outlined by the program. Even though such examples of illegal uses are also depicted in Bekreneva [2012], Vafin [2013], Mun [2013], Aleksandrova [2014], Lavrov and Lapin [2014], this topic is still understudied from a qualitative point of view. In particular, I raise the following question: why do some recipients employ illegal strategies to benefit from the Maternity Capital?

In the first section, I show to what extent recipient families aim to improve not only their housing conditions with help of the Maternity Capital, they also aim to improve their living standards. In the second section, I introduce some administrative, economic and personal constraints faced by these families. Finally, in the third section, I argue that some illegal uses of the Maternity Capital do not conflict with the finalities of the program. In fact, they primarily aim to avoid some constraints.

This study is based on 130 interviews collected between 2015 and 2017 in the Republic of Udmurtia, the Republic of Tatarstan and the Ulyanovsk Region. The informants are: 1) married or in a relationship, 2) living in the town or in the country, and 3) recipients of Maternity Capital.

\footnotetext{
Presidential Address to the Federal Assembly of the Russian Federation (2006), 10 May. Available at: https://www.consultant.ru/document/cons_doc_LAW_60109/\#dst0

2 The Federal Law dated 27.12.2006 № 256-FZ “On additional measures of state support for families with children”. Available at: https:/www.consultant.ru/document/cons_doc_LAW_64872/
} 


\section{Legal uses of the Maternity Capital}

In this section, I introduce three uses of Maternity Capital which are legal under the regulation of the program: 1) the purchase of a first home; 2) the expansion of the living space; and $\mathbf{3}$ ) the funding of a building project.

\section{Purchase of a first home}

The purchase of a first home with the Maternity Capital can be realized with or without a mortgage.

In the first case, the recipient family can use the Maternity Capital to reduce a new mortgage or to pay off an existing mortgage. These possibilities involve two phases. First, the recipient family sends a certificate delivered by the Pension Fund to the bank. Second, the Pension Fund transfers the sum of Maternity Capital to the bank within 6 weeks.

Richard [2014, p. 102] points out that mortgages represent only $3 \%$ of the Russian GDP in 2007 (the year when Maternity Capital was introduced). By way of comparison, mortgages represent $50 \%$ of GDP in the European Union. For this reason, Zaviska [2013, p. 69] argues that the goal of Maternity Capital is not limited to the improvement of the Russian demographic situation, but it also represents an attempt to develop the mortgage market. The statistics of the Pension Fund [Godovoj otchet Pensionnogo Fonda 2016, p. 71] show that one in two families use the Maternity Capital in parallel with mortgages. More interestingly, Toropova and Nivorozhkina [2015, p. 4] highlight that the recipients of Maternity Capital more frequently declare a willingness to take a mortgage than non-recipient families ${ }^{3}$. An interview illustrates the relation between the introduction of Maternity Capital and the use of mortgages.

In fact, the most realistic way to use the maternity capital is with a mortgage. Without it, we would have bought a horrible old house. We had no choice. It is impossible to use the maternity capital without a mortgage, because the Pension Fund requires good quality accommodation. [...] Without the maternity capital, we would never have taken such a mortgage, of course (Alsu, 28 years old).

Families improving their housing conditions without a mortgage are generally observed in rural areas. This is explained by the fact that dwellings are cheaper there. For instance, the house in figure 1 was paid exclusively with the sum of the Maternity Capital obtained by Olga. This house is situated in a village approximately 40 kilometers from Izhevsk (the capital of the Udmurt Republic).

Olga explains that her decision to live in the country was motivated by economics:

We bought this house with the maternity capital. It cost 300,000 rubles [about 4,300 euros]. At that time, my husband died when I was pregnant. My husband died on 4 September and

\footnotetext{
3 The author bases his argumentation on the results of the study "Parents and children, men and women in the family and in the society" (Russian: "Roditeli i deti, muzhchiny i zhenshchiny v sem'e i obshchestve").
} 
I gave birth on 16 September. How did we find this house? Svetlana Evgenevna, who works at the administration, helped me. She said there is a house for sale in Urom. But she also said: "I dont't know if you want to live in Urom". But I did not have any choice and I took the decision to move (Olga, 40 years old).

In the data, families using a mortgage have a uniform profile, i.e. they belong to the middle class and they live in urban areas. Other families are more heterogeneous. Such heterogeneity could be related to the fact that the purchase of a rural dwelling is generally more accessible. In sum, the benefits of Maternity Capital are not limited to the acquisition of a home. It also allows some people to access urban areas.

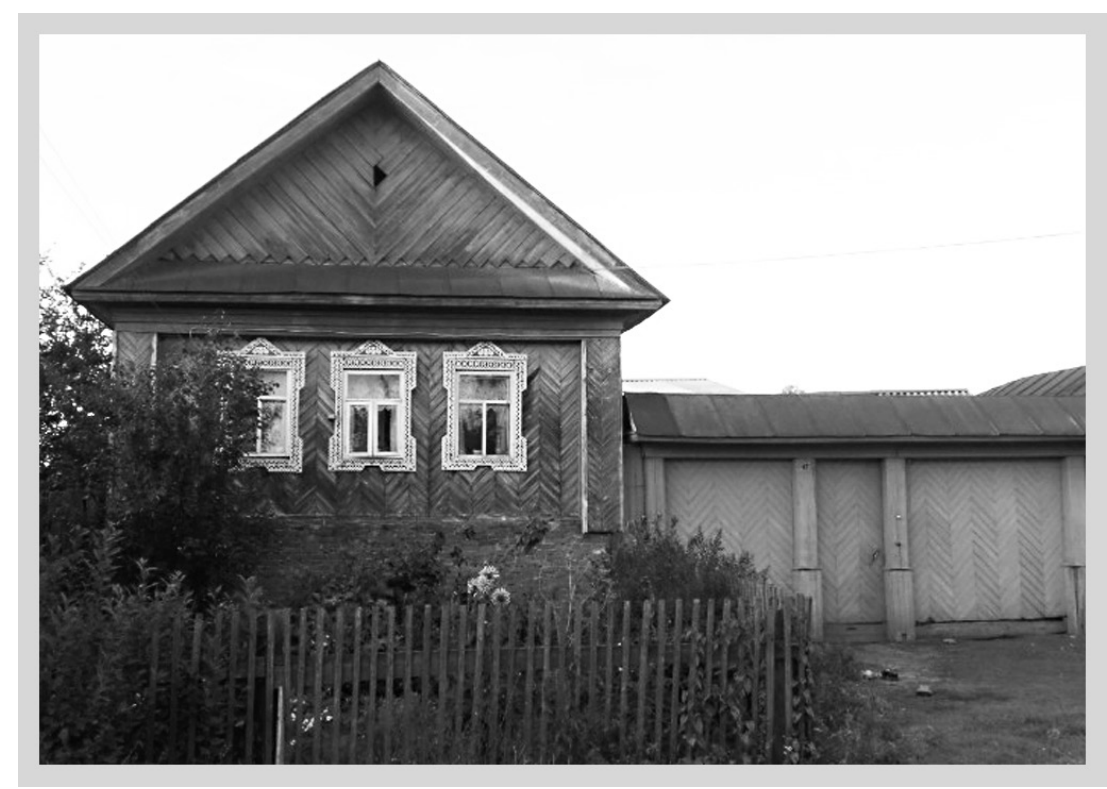

Figure 1. A house bought outright with the Maternity Capital

(Republic of Udmurtia, village, fieldwork 2015)

\section{A larger home}

This section describes how families who already have a home expand their living area.

Maternity Capital can be used to expand a living area by: 1) building an extension to the home (generally to a detached house); or 2) replacing the actual home (generally an apartment) with a bigger one. In both cases, the recipient families must be owners of the refurbished or replaced dwelling.

The expansion of the living area by building an extension takes place in two stages. First, the Pension Fund transfers $50 \%$ of the Maternity Capital to the recipient family's account within two months. Then, the recipient family receives the rest of the Capital six 
months later, provided that most of the work has been done ${ }^{4}$. In this way, some families can double their living area.

We have a wooden house, with one $53 \mathrm{~m}^{2}$ room. We have three children. Moreover, my mother lives with us. In short, there is not enough space. Thanks to the Maternity Capital, we are going to extend our house. We plan to build a room roughly corresponding to the size of this one (Roza, 30 years old).

However, the Maternity Capital regulations require the newly constructed area to be "habitable". This means that this area must be livable all year round. In order to warrant this habitability, the local commission of the Pension Fund can check the quality of the work.

Initially, we decided to use the Maternity Capital to build a veranda on our house. But when we finished it and asked for the rest of the capital, the administration came to check everything. They said that the extension of the living area should be habitable both during summer and during winter. It was necessary to caulk the veranda. Finally, we changed it into a bedroom for our older son (Inna, 40 years old).

The second type of expansion mostly concerns families with an apartment. Elvira explains that her $30 \mathrm{~m}^{2}$ apartment, inherited from her grandmother, became too small after the birth of her second child. Precarious housing conditions motivated her decision to acquire a new apartment with the Maternity Capital.

The apartment we sold was a gift from my grandmother. It was my wedding present. We sold it and, with the Maternity Capital, we bought a bigger apartment. This expanded our area by $10 \mathrm{~m}^{2}$. Initially, we lived in a $30 \mathrm{~m}^{2}$ space. Now, we live in a $40 \mathrm{~m}^{2}$ two room apartment. This flat is completely refurbished and comfortable compared with the previous one, where we were tightly squeezed. In fact, people are always tightly squeezed in standard apartment of the khrushevka type $e^{5}$ (Elvira, 35 years old).

After their previous dwelling was sold, some recipient families moved to another city to access new jobs, new schools, etc. In sum, they access new living standards.

\section{Funding a building project}

So far, I have dealt with recipient families acquiring, or expanding an existing, home. In this section, I address the case of families choosing to build a new home with help of Maternity Capital. These families can to buy off the plan, or build a house with or without the help of a construction company ${ }^{6}$.

In the first case, the recipient signs a contract with a property developer. Then, the Pension Fund transfers the sum of the Maternity Capital to the seller within 6 weeks. Sasha says how she bought an apartment this way for her son.

\footnotetext{
4 This use was introduced in 2010, i.e. three years after the introduction of Maternity Capital. In this case, recipients can exceptionally receive the sum of the Maternity Capital (whereas the cashing of this sum is usually prohibited). Recipients can also pay all the costs of the construction. They are subsequently reimbursed by the Pension Fund. Source: Decree of the Government of the Russian Federation No 20 (2009) January 13 "On amendments to the rules dealing with Maternal Capital to improve housing conditions". Available at: https://base.garant.ru/12164519/

5 A type of apartment built in the 1960s following a standard model.

6 All my informants built their home by their own means, because they consider that construction companies are too expensive.
} 
We took a mortgage at Sberbank. One of the main conditions was to buy off the plan. We proceeded in the following way: first, we took a mortgage, and then, we reimbursed a part of the mortgage with the Maternity Capital. The construction of this apartment finished this year. Now, we need to find the money to carry out interior work (Sasha, 35 years old).

Other families decide to build their future home by their own means. In this case, the procedure is the same as for the expansion of the living area. First, the Pension Fund transfers $50 \%$ of the Maternity Capital to the recipient family's account within two months. Provided that the main work is done, the recipient family receives the rest of the Maternity Capital six months later. For instance, this sum helped Polina to cover a third of the expenditures under the construction of her house in figure 2.

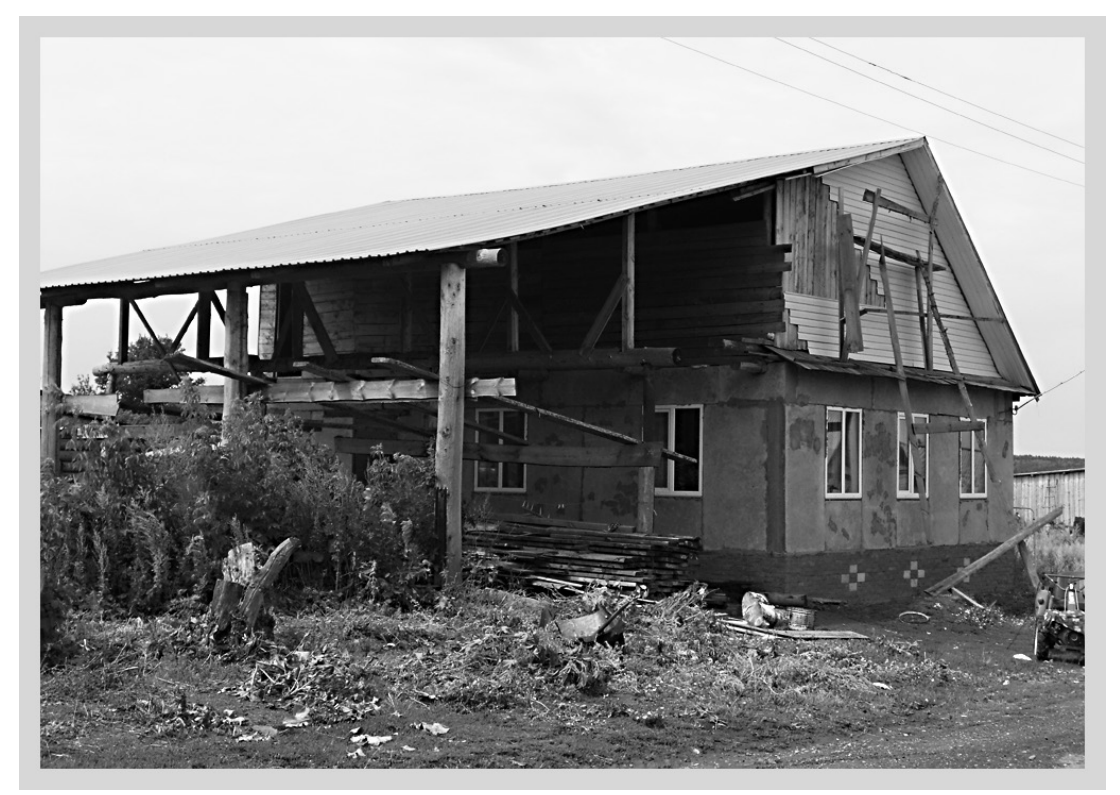

Figure 2. A house extended using the Maternity Capital

Republic of Udmurtia, village, fieldwork 2015

In order to finish a construction project, some families seek complementary financial contributions from other federal programs. Polina explains how she managed to build her house by combining Maternity Capital, which helped her to initiate the building project, and the program "Development of the countryside", ${ }^{7}$ which helped her finish it.

In our case, the Maternity Capital covered a third of the work. Without this program, we would never have started this building project. This way, we could participate to the program "Development of the countryside". In this program, participating families must live and work

7 The federal program "Development of the countryside 2014-2020" (Russian: "Ustoychivoe razvitie sel'skih territoriy na 2014- 2017 gody i na period do 2020 goda") was introduced in order to improve living standards for the rural population // https://rg.ru/pril/83/70/73/598_fcp.pdf 
in a rural area. Additionally, they must undertake at least $30 \%$ of the building work. We received 900,000 rubles [13,000 euros] in addition to the Maternity Capital. This enabled us to finish the building project that we started with the Maternity Capital (Polina, 40 years old).

In the next section, I address the limits and the difficulties related to the application of this program.

\section{Constraints of Maternity Capital}

Despite the high degree of satisfaction with Maternity Capital (95\% of the Russian population had a favorable opinion of the program in $2016^{8}$ ), some recipient families had difficulties or limitations. These limits can also be observed quantitatively in the declining use of the program in recent years [Gorina 2016, p. 2]. These lower utilization rates can be explained by restrictions in the use of the Maternity Capital [Elizarov 2014]. This section analyses three types of restrictions: 1) administrative constraints, 2) economic constraints, and $\mathbf{3}$ ) personal constraints.

\section{Administrative constraints}

The administrative constraints evoked during my interviews were the limited uses of the Maternity Capital and the procedures involved in obtaining an agreement from the Pension Fund.

First, a majority of the interviewed families mention a lack of possible uses (see also [Vovk 2007; Borozdina, Rotkirch, Temkina, Zdravomyslova 2016; Yarskaya-Smirnova 2010]). In most cases, informants complained that the purchase of a vehicle and the purchase of land are prohibited. For example, Anna cannot use the Maternity Capital for a building project because she needs land before building a new home.

After we got married, we started to live with the parents of my husband. We dreamed of having our own house. I would like to use the Maternity Capital to buy land in order to build a house. But, the law prohibits it. Consequently, I can't use the capital as I want and I don't want to use it in some other way (Anna, 28 years old).

Secondly, even within the program, the Pension Fund can also refuse a transfer if: 1) the housing conditions are not improved; 2) the dwelling is considered substandard; or 3) the family is suspected of using the Maternity Capital illegally ${ }^{9}$. Svetlana explains that she got a refusal from the Pension Fund because the home she wanted to purchase was not considered habitable.

Well, everything transits through the Pension Fund where we live. And I can tell you that they do not always understand what they should or should not do. For example, they can be suspicious, and they can refuse to fund your project with the Maternity Capital. This happened

\footnotetext{
8 This survey was done by "Public Opinion" (Russian: "Obshchestvennoe mnenie"). It was carried out on 16 October 2016 with 1,500 Russian citizens aged over 17 years, in 104 municipalities distributed between 54 federal subjects. The statistical error does not exceed 3.6\%.//http://www.image-factor.ru/news/research-news/?ELEMENT_ID=2038

9 These three conditions were listed by the director of the Pension Fund of Tatarstan Republic during an interview.
} 
to me. We were refused because we wanted to buy part of a house, not the whole house. This is not prohibited by law. But, when I went to the Pension Fund, they told me directly: "What part of the house do you want to buy? Maybe the toilet or the terrace?" (Svetlana, 33 years old).

Similarly, El'za decided to purchase a home with a mortgage only because she expected a refusal from the Pension Fund.

I think that it was practically impossible to use the Maternity Capital in order to purchase an individual house in our case, because the Pension Fund checks everything. Initially, we wanted to buy a little $30 \mathrm{~m}^{2}$ house but there was no toilet in it. Then, we understood that the Pension Fund would reject our project (El'za, 30 years old).

In sum, the administrative constraints can lead some recipient families to adopt circumventing strategies in order to benefit from the program.

\section{Economic constraints}

Even though the sum of the Maternity Capital increased from 250,000 rubles (3,600 euros) to 453,026 rubles $(7,000$ euros) between 2007 and 2015, the majority of the informants consider the sum of the Maternity Capital to small to improve their housing conditions. This problem especially concerns families purchasing their first home. Al'bina says that the Maternity Capital can cover only one third of her apartment in Zelenodolsk.

The sum of the Maternity Capital is inadequate for the purchase of any dwelling. When I gave birth to my second child, the capital was 300,000 rubles, if I am not mistaken. Today it is 400,000 rubles. But what dwelling can we buy with only 400,000 rubles? None, of course. An apartment with one room costs at least 1.5 million or 2 million rubles (Al'bina, 33 years old).

Recipient families must have sufficient financial resources to finalize the acquisition of a home. Families without such resources can get a mortgage. However, banks usually require a stable economic situation and a significant income, as illustrated in the interview with Sasha who wants to buy the apartment for her son.

Sasha: Initially, my salary was not enough to get a mortgage. Interest rates are very high and we additionally have to prove that we can pay them.

S.R.: What was your salary during this time?

Sasha: I earned 25,000 rubles per month. Moreover, my husband owns his own apartments. But it was still not enough for the bank. We were refused. When I returned to the labor market after my maternity leave, my salary increased to 50,000 rubles. After six months of activity, we got an approval. Then, we reimbursed a part of the mortgage with the Maternity Capital (Sasha, 35 years old).

The interview with Sasha shows that the average wage in Ulyanovsk (30,876 rubles $[440 \text { euros }]^{10}$ ) is insufficient to get a mortgage. Furthermore, banks do not grant mortgages to customers without a deposit (at least $10 \%$ of the apartment's cost) and the Maternity Capital is not generally accepted as a deposit.

At the bank, we were told that we cannot use the Maternity Capital as a deposit in order to get a mortgage. We were forced to ask for help from our parents to find the needed amount.

10 The results of the social and economic developments of the municipality of Ulyanovsk for January - November 2017. URL: http://www.ulmeria.ru/ru/documents/672. 
Only after that time, we managed to use the Maternity Capital in order to reimburse part of the mortgage (Alsu, 30 years old).

Recipient families with an average wage cannot use the Maternity Capital without a mortgage. The mortgage itself is also difficult to obtain. These economic constraints are reflected by the low utilization rate at the national level. Following the Pension Fund Report from 2016, more than 3.4 million eligible families out of 7.6 million have not used the Maternity Capital yet.

\section{Personal constraints}

Some recipient women wish to be free to use their newly purchased home at their convenience (e.g. resale, property division after a divorce). However, Maternity Capital constrains them to share the property with the other members of the nuclear family (husband and children). The regulation stipulates that a document declaring an equitable sharing between family members must be registered with a notary within six months of a new acquisition [Maslova 2014].

Nevertheless, some women are afraid of having difficulties in reselling their home, because of the authorities handling child protection, who can cancel the sale of a home when they consider that the rights of minor children are not respected (e.g. in case of declining housing conditions) [Nazarova 2015].

In fact, when you purchase a home with the Maternity Capital, the law imposes a property division between the members of the family. But I want to sell this home later on, and it might difficult because of child protection. This is why I think I want to register this home in my name (Masha, 30 years old).

Some women do not wish to divide the property if they divorce. According to the law, all property acquired during the marriage must be equitably divided between the spouses (see article 36 of the Russian Family Code) ${ }^{11}$. For this reason, some women wish to register the property in their name only.

Of course, I trust my husband. But who knows? If we decide to divorce, I do not want to be homeless. This is why I want to register the home I intend to purchase with Maternity Capital in my name. My husband is aware of that and he agrees (Yulya, 28 years old).

Some recipient families face administrative, economic or personal difficulties when they want to use Maternity Capital. In the next section, I show how these families circumvent their difficulties.

\section{Circumventing Maternity Capital}

The Maternity Capital can only be received as a bank transfer. Any cashing of this sum is prohibited and is punishable under article 159 of the Criminal Code ${ }^{12}$. A recipient cashing

\footnotetext{
11 This applies when there is no marriage contract.

12 Any violation renders the offender liable to a fine of up to 120,000 rubles or a prison sentence of up to two years [Maslova 2014, p. 152].
} 
the Maternity Capital commits a criminal offense and can be convicted for embezzlement of public funds. This section argues that the various misuses of the Maternity Capital are not equivalent. For this, I distinguish uses respecting or not respecting the finalities of the program (i.e. the resulting benefits), and uses respecting or not respecting the procedures of the program (table 1). I show to what extent some illegal uses primarily aim to resolve the constraints mentioned in the second section.

Table 1. Uses of Maternity Capital

\begin{tabular}{|c|c|c|}
\hline & Respect of finalities & Non-respect of finalities \\
\hline Respect of procedures & Legal use & Diverted use \\
\hline Non-respect of procedures & Subverted use & Fraudulent use \\
\hline
\end{tabular}

\section{Fraudulent uses}

In the first section, I addressed various legal uses of the Maternity Capital. By definition, these respect both the procedures and finalities of the program. Conversely, some uses do not respect procedures nor finalities. I call these "fraudulent uses".

I previously mentioned that a majority of informants complain about the strong restrictions on Maternity Capital. In this context, some recipient families use agencies offering to cash the Maternity Capital. This type of fraudulent use is generally achieved by acquiring a fictitious dwelling proposed by an estate agency [Mun 2013; Maslova 2014, p. 145; Arkhipova 2014, p. 100]. after the agency receives the transfer from the Pension Fund, it transfers the sum to the recipient family. In this way, Olga managed to buy a tractor.

We purchased a tractor with the Maternity Capital with the help of an estate agency. I don't know how they cash the capital but it was very easy for us. Before, we had to ask our neighbors and extended family for help during the potato harvest, for example. Now, we usually help our neighbors with our tractor. In exchange, they give us money, they pay fuel or they give us a bottle of vodka (Olga, 35 years old).

Olga's decision does not respect the procedures of the Maternity Capital: the cashing of the sum is prohibited by the law. Moreover, the purchase of a tractor with this cash conflicts with the finalities of the program, which initially serves to improve housing conditions. This type of fraudulent use especially concerns families who already own an apartment and do not particularly need to improve their housing conditions; such families wish to improve their living conditions in a more general way.

\section{Diverted uses}

Diverted uses are those respecting the procedures but not the finalities of the program.

Some recipients families wish to cash the Maternity Capital by purchasing the home of their parents without moving there. In this case, the Pension Fund transfers the 
Maternity Capital to the sellers (i.e. the parents) who subsequently transfer this sum to the buyers (i.e. the children). The law does not prohibit the purchase of a dwelling from family members (except spouses). Accordingly, the recipient families involved in such circumventing strategies respect the procedures of the program.

However, the cashed Maternity Capital does not usually serve to improve housing conditions. The purchase of a car is one of the most popular finalities of this diverted use. In that sense, it does not respect the finalities of the program.

We needed a car. To drop the kids off at school, to visit my mother or my parents-in-law, who live in the countryside. I asked my mother if I could buy her house in order to cash the Maternity Capital. My mother trusts me, she knows that we could not leave her homeless. I was afraid that my older sister might disagree. But she didn't say anything. We bought a car in this way (Veronika, 27 years old).

Interestingly, the use of the Maternity Capital to purchase a means of transport triggers an enhancement of family autonomy and new relationships with neighborhood.

Formerly, we needed to borrow our neighbor's car in order to take the kids to preschool or to the hospital, for example. The nearest are $7 \mathrm{~km}$ away. Since we bought a car with the Maternity Capital, this is not a problem anymore. Now, the reverse happens: the other people ask for our car (Valentina, 40 years old).

Diverted uses serve to improve the living standards of a recipient family in a more general way than the possibilities included in the regulation of the Maternity Capital.

\section{Subverted uses}

Subverted uses are those uses respecting the finalities of the program but not its procedures.

We have already seen that recipient families sometimes employ circumventing strategies in order to use the Maternity Capital. These strategies are sometimes considered illegal even if they aim to improve housing conditions. For instance, Tanya faced some difficulties in getting a mortgage. After a refusal from the bank, she decided to cash the Maternity Capital with help of an agency in order to purchase and refurbish a house. Such case is in line with the finalities of the program, even if it does not respect the procedures.

I wanted to get a mortgage to purchase an apartment, and to subsequently reimburse the mortgage with the Maternity Capital. But the bank rejected my project because my pay was too low. Then, I wanted to purchase a house with the Maternity Capital, but I got a refusal from the Pension Fund. They considered that this house is substandard because it does not have communications [i.e. without heating and electricity]. But how can we afford a good enough house in town that can be paid for with the Maternity Capital? Finally, I used an agency to cash the Maternity Capital. In this way, I bought a house that suits us very well. We undertook renovations with the rest of the Maternity Capital (Tanya, 25 years old).

Recipient families can also subvert the administrative constraints. For example, some of them circumvent the prohibition on purchasing land by acquiring a land with an old house. In this case, recipient families do not respect the procedures of the program because the purchased house is usually substandard. This way, these families can start a new construction project by demolishing the former dwelling. 
Natalya: I already knew for some time that there is a little old house with a garden for sale in this village. An old woman used to live there. But she died. Her only son lives far away from here, in the region of Mozhga. I found him and I proposed buying the house. He immediately agreed.

S.R.: How much did you pay?

Natalya: 170,000 rubles. I used the rest of the Maternity Capital to start the construction of my new home. Otherwise, I never could have bought land, even if I wanted to build a house on it. But in this way, we bought this land, we bought building materials and we started our building project (Natalya, 30 years old).

The obligation to share a newly acquired dwelling with other members of the nuclear family is sometimes interpreted as a constraint by some recipient women. In order to solve this issue, they decide to register the newly acquired home in their name only. This is the case of Svetlana, who explains that she prefers to pay a penalty than to face subsequent difficulties with the sale of her dwelling.

It is very difficult to sell a home if it is partially owned by under-age children. I immediately sought advice from my friend [who is a lawyer]. And she told me that I can register the dwelling in my name, because nobody checks it. Even in the worst case, if it does not work, I will be fined of 20,000 rubles (Svetlana, 30 years old).

Lena was in a similar situation ${ }^{13}$. More specifically, she explains how this strategy helped her to initiate a divorce.

I bought an apartment in Kazan with the Maternity Capital. Thanks to this, I could move from Naberezhnye Chelny, my native town, and I could get divorced. I registered this apartment in my name, so I had no big issues with property division. I changed my life and the life of my children radically. This is thanks to the Maternity Capital (Lena, 30 years old).

There are different types of illegal uses. Some of them do not conflict with the intent of the law, but they serve to circumvent specific difficulties. More generally, all recipient families misusing the Maternity Capital intend to improve their living standards.

\section{Conclusion}

Two uses of the Maternity Capital have been presented: legal and illegal. I showed that illegal uses can be very heterogeneous. More specifically, these do not necessarily conflict with the objectives of the program. On the contrary, some of these uses aim to fulfill the same finalities (i.e. the improvement of housing conditions). Nevertheless, constraints are such that they prevent some recipient families from accessing benefits promised by Maternity Capital. These constraints are generally administrative, economic or personal. My claim is that many families illegally use the Maternity Capital in order to circumvent the practical difficulties, not the rules. In other words, these families do not respect the procedures of the program, but they respect its finalities. These illegal uses should not be assimilated with simple fraud, because they highlight the limits of the Maternity Capital in its practical application.

\footnotetext{
13 Maslova points out that a lot of women are in the same situation. She considers that this is because there is no verification mechanism [Maslova 2014, p. 151]. As a consequence, the distribution of the dwelling between family members ipso facto depends on the recipient women.
} 


\section{References}

Aleksandrova I.A. (2014) Zashchishchennost' materinskogo kapitala ot kriminal'nykh ugroz [Protection of the Maternity Capital from the Criminal Threats]. Yuridicheskaya nauka $i$ praktika: Vestnik Nizhegorodskoy akademii MVD Rossii, no 2, pp. 59-63.

Arkhangel'skij V.N. (2014) Otsenka demograficheskoj rezul'tativnosti mer pomoshchi sem'yam $\mathrm{s}$ det'mi v Rossii [Assessment of Demographic Efficiency of Measures of Providing Support to Families with Children in Russia]. Demografiya i sotsial'naya ekonomika, no 1, pp. $108-120$.

Arkhipova O.A. (2014) Materinskij kapital kak predmet moshennichestva [The Maternity Capital as an Object of Fraud]. Vestnik SevKavGTI, no 19, pp. 99-101.

Avdeeva O.A. (2011) Policy Experiment in Russia: Cash-for-babies and Fertility Change. Social Politics, vol. 18, no 3, pp. 361-386.

Bekreneva T. (2012) Meterinskij kapital - povod dlya moshennichestva [The Maternity Capital Is Pretexte to Scam]. Zhilishchnoe pravo, no 4, pp. 57-63.

Bol'shinstvo rossiyan znaet o materinskom kapitale i podderzhivaet dannuyu meru (2016) [Most Russians Know about Maternity Capital and Support This Measure]. Image-factor.ru. Available at: http://www.image-factor.ru/news/research-news/?ELEMENT ID=2038, accessed 31 May 2018.

Borozdina E., Zdravomyslova E., Temkina A. (2011) Materinskij kapital: sotsial'naya politika i strategii semej [The Maternity Capital: Social Policy and Strategies of the Families]. GenderPage.ru. Available at: http://genderpage.ru/?p=481, accessed 31 May 2018.

Borozdina E., Rotkirch A., Temkina A., Zdravomyslova E. (2016) Using Maternity Capital: Citizen Distrust of Russian Family Policy. European Journal of Women's Studies, vol. 23, no 1 , pp. 60-75.

Chernova Z. (2011) Semejnaya politika sovremennoj Rossii: gendernyj analiz i otsenka effektivnosti [Contemporary Russian Family Policy: Gender Analysis and Evaluation of Efficiency]. Zhenshchina v Rossiyskom Obshchestve, no 3, pp. 44-51.

Chernova Z. (2012) New Pronatalism?: Family Policy in Post-Soviet Russia. REGION: Regional Studies of Russia, Eastern Europe, and Central Asia, no 1, pp. 75-92.

Elizarov E. (2014) Svobodno i otvetstvenno [Freely and Responsibly]. Aktual'nye kommentarii. Available at: http://actualcomment.ru/svobodno_i_otvetstvenno.html, accessed 31 May 2018.

Federal'naya tselevaya programma «Ustoychivoye razvitie sel'skikh territorij 2014-2017 i na period do 2020 goda» [The Federal Program "Development of the Countryside 2014-2020"]. Garant.ru. Available at: http://www.garant.ru/products/ipo/prime/doc/70319016/, accessed 31 May 2018.

Federal'nyj zakon No 256 - FZ ot 29 dekabrya 2006 g. «O dopolnitel'nykh merakh gosudarstvennoj podderzhki semej, imeyushchih detej» [The Federal Law dated 27.12.2006 No 256-FZ "On Additional Measures of State Support for Families with Children"]. Consultant.ru. Available at: https://www.consultant.ru/document/cons_doc_LAW_64872/, accessed 31 May 2018.

Godovoj otchet Pensionnogo Fonda Rossijskoj Federatsii (2016) [Annual Report of the Pension Fund of the Russian Federation]. Pension Fund of the Russian Federation. Available at: http://www.pfrf.ru/press_center/advert materials/ 2074, accessed 31 May 2018.

Gorina E.A. (2016) Obshchie tendentsii i regional'naya spetsifika v rasporyazhenii sredstvami materinskogo kapitala v Rossii [General Trends and Regional Specificity in Using of the Maternity Capital in Russia]. Voprosy ekonomiki, no 2, pp. 111-127.

Itogi sotsial'no- ekonomicheskogo razvitiya munitsipal'nogo obrazovaniya «Gorod Ulyanovsk» za yanvar' - noyabr' 2017 goda [Results of the Social and Economic Developments of the Municipality of Ulyanovsk for January - November 2017]. Ulmeria.ru. Available at: http://www.ulmeria.ru/ru/documents/672, accessed 31 May 2018.

Lavrov V.P., Lapin V.O. (2014) Sposoby nezakonnogo obnalichivaniya byudzhetnykh sredstv, vydelyaemykh na vyplatu materinskogo (semejnogo) kapitala: obshchaya kharakteristika 
i etapy razvitiya [Ways of Illegal Cashing of Budget Funds Allocated to the Payment of the Maternity (Family) Capital: Common Characteristics and Stages of the Development]. Trudy Akademii upravleniya MVD Rossii, no 3, pp. 105-108.

Maslova T.A. (2014) Materinskij kapital: kak poluchit'i rasporyaditsya [The Maternity Capital: How to Get and How to Use], Moscow: Bibliotechka RG.

Materialy ob okonchatel'nykh itogakh Vserosijskoj Perepisi naseleniya 2010 goda [Materials about the Final Results of the National Population Census 2010]. Federal State Statistics Service. Available at: http://www.gks.ru/free_doc/new_site/perepis2010/croc/perepis itogi1612.htm, accessed 31 May 2018.

Mun O. (2013) Makhinatsii s materinskim kapitalom [Frauds with Maternal Capital]. Zhilishchnoe pravo, no 6, pp. 7-29.

Nazarova S. (2015) Narushenie prav nesovershennoletnikh pri prodazhe nedvizhimosti (zhilykh domov, zemel'nykh uchastkov) [Violation of the Rights of Minors at Property Sale (Houses, the Land Plots)]. Zhilishchnoe pravo, no 12, pp. 89-100.

Pecherskaya N. (2012) Mifologiya roditel'stva: analiz diskursivnogo proizvodstva ideal'noj sem'i [The Mythology of Parenthood: an Analysis of the Discursive Production of the Ideal Family]. Zhurnal issledovanij sotsial'noj politiki, vol. 10, no 3, pp. 323-342.

Poslanie Prezidenta Federal'nomu sobraniyu Rossijskoj Federatsii ot 10 mya 2006 goda [Presidential Address to the Federal Assembly of Russian Federation (2006) 10 May]. Consultant.ru. Available at: https://www.consultant.ru/document/cons_doc_LAW_60109/\#dst0, accessed 31 May 2018.

Postanovlenie Pravitelstva Rossijskoj Federatsii No 20 ot 13 yanvarya 2009 g. «O vnesenii izmenenij $\mathrm{v}$ pravila napravleniya sredstv (chasti sredstv) materinskogo (semejnogo) kapitala na uluchshenie zhilishchnykh uslovij»» [Decree of the Government of the Russian Federation No 20 (2009) January 13 "On Amendments to the Rules Dealing with Maternal Capital to Improve Housing Conditions"]. Garant.ru. Available at: https://base.garant. ru/12164519/, accessed 31 May 2018.

Radvanyi J., Laruelle M., Pawlotsky V. (2016) La Russie, Entre Peurs et Défis. Revue d'Etudes Comparatives Est-Ouest, no 4, pp. 181-186.

Richard H. (2014) Comment les Russes Sont-Ils devenus (co) Propriétaires? (Doctoral dissertation, Université de Lyon).

Rivkin-Fish M. (2010) Pronatalism, Gender Politics, and the Renewal of Family Support in Russia: Toward a Feminist Anthropology of "Maternity Capital". Slavic Review, vol. 69, no 3, pp. 701-724.

Rosstat (2016) Official Statistics. Demography. Federal State Statistics Service. http://www.gks.ru/wps/wcm/connect/rosstat_main/rosstat/ru/statistics/population/ demography/\#

Semejnyj kodeks Rossijskoj Federatsii [The Family Code of the Russian Federation]. Consultant.ru. Available at: http://www.consultant.ru/document/cons_doc_LAW_8982/d9720d9bf40b191 45687c99c5e7da8ed4abdef8a/, accessed 31 May 2018.

Slonimczyk F., Yurko A. (2014) Assessing the Impact of the Maternity Capital Policy in Russia. Labour Economics, no 30, pp. 265-281.

Toporova T.V., Nivorozhkina L.I. (2015) Vozdejstvie materinskogo kapitala na istitut ipotechnogo kreditovaniya: modelirovanie povedeniya domokhozyastv [Impact of the Maternity Capital to the Institute of Mortgage Lending: Modeling of the Family's Household Behavior]. Proceedings of the XVI April International Academic Conference on Economic and Social Development. Moscow: HSE.

Vafin E.Ya. (2013) Materinskij kapital: realizatsiya federal'nogo zakona ot 29.12.2006 No 256 FZ «o dopolnitel'nykh merakh gosudarstvennoj podderzhki semej, imeyushchijh detej» [The Maternity Capital: Implementation of the Federal Law dated 27.12.2006 No 256-FZ "On Additional Measures of State Support for Families with Children"]. Aktual'nye voprosy ekonomicheskikh nauk, no 31, pp. 122-125.

Vichnevski A. (2009) Les Enjeux de la Crise Démographique en Russie. Russie. Nei. Visions, 41, IFRI.

Vovk E. (2007) Otnoshenie rossiyan k materinskomu kapitalu [Attitude of Russian Citizens to the Maternity Capital]. Sostial'naya real'nost', no 7, pp. 30-35. 
Yarskaya-Smirnova E. (2010) «Da-da, ya vas pomnyu, vy zhe u nas neblagopoluchnaya semya!» Diskursivnoe oformlenie sovremennoj rossijskoj politiki ["Yes, I Remember You, You are that Problem Family!" Discursive Shaping of Contemporary Russian Policy]. Zhenschina v rossijskom obschestve, no 2, pp. 14-25.

Zaharov S., Frejka T. (2012) Comprehensive Analyses of Fertility Trends in the Russian Federation during the Past Half Century, MPIDR Working Paper, WP-2012-027, Rostock.

Zakharov S. (2008) Rossijskaya rozhdaemost' - dolgozhdannyj rost? [The Russian Fertility Is the Long-overdue of Growth?]. Demoscop Weekly, no 353-354. Available at: http://www.demoscope.ru/weekly/2008/0353/tema01.php

Zaviska J.R. (2012) Housing the New Russia, Cornell University Press.

\title{
Незаконное использование материнского капитала в России
}

\author{
С.Н. РУССКИХ*
}

*Светлана Николаевна Русских - аспирантка, социологический факультет, University of Paris Descartes; The Institute for Demographic Studies (INED). Aдрес: 12 l'École de Médecine St., Paris, 75006, France. E-mail: svetlana.russkikh@gmail.com

Цитирование: Russkykh S. (2018) Illegal Uses of the Russian Maternity Capital. Mir Rossii, vol. 27, no 3, pp. 180-197. DOI: 10.17323/1811-038X-2018-27-3-180-197

Статья посвящена пронаталистской политике в современной России. Основное внимание уделено программе «Материнский капитал», целью которой является стимулирование вторых рождений. В статье проанализированы законные и незаконные способы использования материнского капитала российскими семьями. Законом предусмотрено всего четыре направления по использованию данной программы: (1) улучшение жилищных условий, (2) образование детей, (3) формирование будущей пенсии матери и (4) приобретение товаров и услуг для детей-инвалидов.

При использовании материнского капитала российские семьи сталкиваются с административными, экономическими и личными трудностями. Административные трудности связаны прежде всего с ограничениями в использовании материнского капитала. Но некоторые семьи также получают отказ со стороны Пенсионного Фонда на использование капитала для улучшение своих жилищных условий. Экономические трудности заключаются в том, что сумма материнского капитала оказывается слишком незначительной, чтобы за ее счет можно было приобрести жилое помещение. Семьи, которые не имеют стабильных доходов или дополнительных экономических ресурсов, оказываются в ситуации, когда они нуждаются в улучшении своих жилищных условий, но при этом не могут воспользоваться программой. Наконец, личные трудности связаны с тем, что некоторые матери хотят оформить жилье, приобретенное на материнский капитал, на 
себя (например, во избежание раздела жилья с супругом в случае развода). Данное решение противоречит закону, так как приобретенное жилое помещение на материнский капитал должно быть оформлено в общую долевую собственность всех членов семьи.

Для того чтобы справиться с данными трудностями, некоторые семьи прибегают к незаконному использованию материнского капитала: (1) нелегальное использование, (2) нецелевое использование и (3) нерегламентированное использование. Нелегальное использование заключается в обналичивании материнского капитала незаконным путем. После этого семья распоряжается полученной суммой по направлению, не предусмотренному законом (например, на покупку автомобиля). При нецелевом использовании материнского капитала обналичивание происходит законным путем (например, семья покупает жилье у родителей), но конечной целью такого сделки остается использование капитала по направлению, которое закон не предусматривает. При нерегламентированном использовании материнского капитала обналичивание происходит незаконным путем, но его конечной целью является использование капитала по направлению, которое входит в рамки закона (например, улучшение жилищных условий).

Таким образом в статье показано, что программа материнского капитала имеет несовершенства механизма реализации, и некоторые семьи вынужденно прибегают к его обналичиванию с целью преодоления трудностей, а не с целью использования капитала по направлениям, которые не предусмотрены законом.

Ключевые слова: материнский капитал, мошенничество, незаконное обналичивание, семья, семейная политика, пронатализм, Россия

\section{Литература}

Александрова И.А. (2014) Защищенность материнского капитала от криминальных угроз // Юридическая наука и практика: Вестник Нижегородской академии МВД России. № 2. С. 59-63.

Архангельский В.Н. (2014) Оценка демографической результативности мер помощи семьям с детьми в России // Демографія та соціальна економіка. № 1. С. 108-120.

Архипова О.А. (2014) Материнский капитал как предмет мошенничества // Вестник СевКавГТИ. № 19. С. 99-101.

Бекренева Т. (2012) Материнский капитал - повод для мошенничества // Жилищное право. № 4. С. 57-63.

Большинство россиян знает о материнском капитале и поддерживает данную меру // Imagefactor.ru // http://www.image-factor.ru/news/research-news/?ELEMENT_ID=2038

Бороздина Е., Здравомыслова Е., Темкина А. (2011) Материнский капитал: социальная политика и стратегии семей // Гендерные страницы // http:/genderpage.ru/?p=481

Вафин Э.Я. (2013) Материнский капитал: реализация федерального закона от 29. 12. 2006 № 256-Ф3 «О дополнительных мерах государственной поддержки семей, имеющих детей» // Актуальные вопросы экономических наук. № 31. С. 122-125.

Вовк Е. (2007) Отношение россиян к материнскому капиталу // Социальная реальность. № 7. С. 30-35.

Годовой отчет Пенсионного Фонда Российской Федерации (2016) // Пенсионный Фонд Российской Федерации // http://www.pfrf.ru/press_center/advert_materials/ 2074 
Горина Е.А. (2016) Общие тенденции и региональная специфика в распоряжении средствами материнского капитала в России // Вопросы экономики. № 2. С. 111-127.

Елизаров В. (2014) Свободно и ответственно // Актуальные комментарии // http://actualcomment.ru/svobodno i otvetstvenno.html

Захаров С. (2008) Российская рождаемость - долгожданный рост? // Демоскоп Weekly. № 353-354 // http://www.demoscope.ru/weekly/2008/0353/tema01.php

Итоги социально-экономического развития муниципального образования «город Ульяновск» за январь-ноябрь 2017 г. // Администрация города Ульяновск // http://www.ulmeria.ru/ru/documents/672

Лавров В.П., Лапин В.О. (2014) Способы незаконного обналичивания бюджетных средств, выделяемых на выплату материнского (семейного) капитала: общая характеристика и этапы развития // Труды Академии управления МВД России. № 3. С. 105-108.

Маслова Т.А. (2014) Материнский капитал: как получить и распорядиться. М.: Библиотечка РГ.

Материалы об окончательных итогах Всероссийской Переписи населения 2010 года // Федеральная служба государственной статистики // http://www.gks.ru/free doc/new site/perepis2010/croc/perepis itogi1612.htm

Мун О. (2013) Махинации с материнским капиталом // Жилищное право. № 6. С. 7-29.

Назарова С. (2015) Нарушение прав несовершеннолетних при продаже недвижимости (жилых домов, земельных участков) // Жилищное право. № 12. С. 89-100.

Печерская Н.В. (2012) Мифология родительства: анализ дискурсивного производства идеальной семьи // Журнал исследований социальной политики. № 3. С. 323-342.

Послание Президента Федеральному собранию Российской Федерации от 10 мая 2006 г. // Consultant.ru // https://www.consultant.ru/document/cons doc LAW 60109/\#dst0

Постановление Правительства РФ N 20 от 13 января $200 \overline{9}$ г. «О внесении изменений в Правила направления средств (части средств) материнского (семейного) капитала на улучшение жилищных условий» // Garant.ru // https://base.garant.ru/12164519/

Росстат (2016) Официальная статистика. Демография. // Федеральная служба государственной статистики // http://www.gks.ru/wps/wcm/connect/rosstat_main/rosstat/ru/ statistics/population/demography/\#

Семейный кодекс Российской Федерации // Consultant.ru http://www.consultant.ru/document/ cons doc LAW 8982/d9720d9bf40b19145687c99c5e7da8ed4abdef8a/

Торопова Т.В., Ниворожкина Л.И. (2015) Воздействие материнского капитала на институт ипотечного кредитования: моделирование поведения домохозяйств // Материалы XVI Апрельской Международной научной конференции «Модернизация экономики и общества». М: ВШЭ. С. 162-169.

Федеральный закон N 256-Ф3 от 29 декабря 2006 г. «О дополнительных меpax государственной поддержки семей, имеющих детей» // Consultant.ru // https://www.consultant.ru/document/cons_doc_LAW_64872/

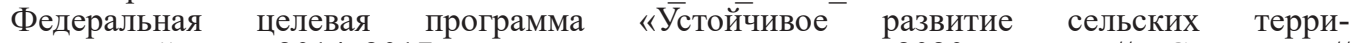
торий на 2014-2017 годы и на период до 2020 года» // Garant.ru // http:/www.garant.ru/products/ipo/prime/doc/70319016/

Чернова Ж.В. (2011) Семейная политика современной России: гендерный анализ и оценка эффективности // Женщина в российском обществе. № 3. С. 44-51.

Ярская-Смирнова Е.Р. (2010) «Да-да, я вас помню, вы же у нас неблагополучная семья!» Дискурсивное оформление современной российской семейной политики // Женщина в российском обществе. № 2. С. 14-25.

Avdeyeva O.A. (2011) Policy Experiment in Russia: Cash-for-babies and Fertility Change // Social Politics, vol. 18, no 3, pp. 361-386.

Borozdina E., Rotkirch A., Temkina A., Zdravomyslova E. (2016) Using Maternity Capital: Citizen Distrust of Russian Family Policy // European Journal of Women's Studies, vol. 23, no 1 , pp. 60-75.

Chernova Z. (2012) New Pronatalism? Family Policy in Post-Soviet Russia // REGION: Regional Studies of Russia, Eastern Europe, and Central Asia, no 1, pp. 75-92.

Radvanyi J., Laruelle M., Pawlotsky V. (2016) La Russie, Entre Peurs et Défis // Revue d'Etudes Comparatives Est-Ouest, no 4, pp. 181-186. 
Richard H. (2014) Comment les Russes Sont-Ils devenus (co) Propriétaires? (Doctoral dissertation, Université de Lyon).

Rivkin-Fish M. (2010) Pronatalism, Gender Politics, and the Renewal of Family Support in Russia: Toward a Feminist Anthropology of "Maternity Capital" // Slavic Review, vol. 69, no 3, pp. 701-724.

Slonimczyk F., Yurko A. (2014) Assessing the Impact of the Maternity Capital Policy in Russia // Labour Economics, no 30, pp. 265-281.

Vichnevski A. (2009) Les Enjeux de la Crise Démographique en Russie // Russie. Nei. Visions, 41, IFRI.

Zaharov S., Frejka T. (2012) "Comprehensive Analyses of Fertility Trends in the Russian Federation during the Past Half Century", MPIDR Working Paper, WP-2012-027, Rostock. Zaviska Jane R. (2012) Housing the New Russia, Cornell University Press. 